\title{
Pengaruh Penambahan Minyak Buah Merah Terhadap Kualitas Organoleptik Nugget Ayam
}

\section{Organoleptic Quality of Chicken Nuggets Added With Red Fruit Oil}

\author{
Ester Sadolona ${ }^{\mathrm{a}, 1}$, Rivana Agustin ${ }^{\mathrm{b}, 2}$ \\ ${ }^{a}$ Widyaiswara Balai Latihan Pertanian Sentani Dinas Pertanian dan Pangan Provinsi Papua, Jl. Yahim Dobonsolo Sentani Papua

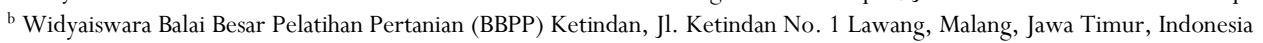 \\ ${ }^{1}$ sadolona.quinn18@gmail.com; ${ }^{2}$ rivviolet@gmail.com* \\ * corresponding author
}

INFO ARTIKEL ABSTRACT / ABSTRAK

\begin{abstract}
Sejarah Artikel Tanaman buah merah adalah tanaman endemik Papua. Kandungan senyawa aktif dalam buah
Dikirim:

20 November 2021

Diterima:

15 Desember 2021 merah diantaranya adalah karotenoid, tokoferol, asam oleat, asamlinoleat, dekanoat, protein, vitamin B dan vitamin C. Sehingga buah merah diyakini mampu menangkal radikal bebas yang dapat menyebabkan kerusakan sel atau penyakit degeneratif, meningkatkan stamina dan menjaga daya tahan tubuh. Dengan kandungan zat gizi yang tinggi pada buah merah, maka dapat

Terbit: berpotensi untuk dijadikan sebagai bahan tambahan pangan. Salah satunya memanfaatkan minyak buah merah untuk ditambahkan ke produk nugget ayam sebagai bahan fortifikasi, pewarna makanan alami sekaligus penambah citarasa. Pengkajian ini bertujuan untuk mengetahui uji

27 Desember 2021 organoleptik nugget ayam terhadap warna, aroma, tekstur dan rasa nugget ayam pada berbagai persentase penambahan minyak buah merah, sehingga minyak buah merah dapat dimanfaatkan sebagai produk pangan olahan pangan lokal dan lebih bergizi serta dapat diterima oleh masyarakat. Penelitian ini terdapat 4 (empat) perlakuan penambahan minyak buah merah yakni $(0 \%, 0,5 \%, 1 \%$ dan $1,5 \%)$. Hasil analisa uji organoleptik yang dilakukan terhadap produk nugget ayam dengan penambahan minyak buah merah didapatkan aroma dengan kisaran nilai rataan 3,50 hingga 3,70 dengan kategori agak suka. Pada konsentrasi penambahan minyak buah merah 1,5\% dihasilkan kategori suka. Pada konsentrasi penambahan minyak buah merah 0,5\% dihasilkan tekstur yang renyah dengan nilai 3,90. Pada konsentrasi penambahan minyak buah merah 1\% dikategorikan rasa yang enak dengan nilai 3,90.
\end{abstract}

The red fruit plant is an endemic plant of Papua. The content of active compounds in red fruit include carotenoids, tocopherol, oleic acid, linoleic acid, dexanoate acid, protein, vitamin B and vitamin C. So red fruit is believed to be able to ward off free radicals that can cause cell damage or degenerative diseases, increase stamina and maintain endurance. With a high nutritional content in red fruit, it can potentially be used as a food additive. One of them uses red fruit oil to be added to chicken nuggets products as a fortified ingredient, natural food coloring as well as flavor enhancers. This study aims to find out the organoleptic test of chicken nuggets on the color, flavour, texture and taste of chicken nuggets at various percentages of red fruit oil addition, so that red fruit oil can be used as a local food processed food product and more nutritious and acceptable to the public. This study has 4 (four) treatments of red fruit oil additions, namely $(0 \%, 0.5 \%, 1 \%$ and $1.5 \%)$. The results of organoleptic test analysis conducted on chicken nuggets products with the addition of red fruit oil obtained flavour with an average value range of 3.50 to 3.70 with a rather preferred category. At the concentration of red fruit oil addition $1.5 \%$ produced category likes. At the concentration of ref fruit oil addition $0.5 \%$ produced a crunchy texture with a value of 3.90 . At the concentration of red fruit oil addition 1\% categorized as good taste with a value of 3.90

This is an open access article under the CC-BY license.

Kata Kunci: Minyak buah merah, Nugget ayam, Organoleptik

Keywords: Red fruit oil, Chicken nuggets, Organoleptic

\section{Pendahuluan}

Nugget ayam merupakan rekonstruksi dari olahan serpihan daging yang dibentuk sedemikian rupa dengan penambahan bahan-bahan tertentu sehingga membentuk produk baru yang diterima oleh masyarakat. Menurut SNI (2002) nugget ayam merupakan produk olahan gilingan daging ayam yang dicetak, dimasak dan dibekukan 
dengan penambahan bahan-bahan tertentu yang diijinkan. Nugget merupakan makanan siap saji yang banyak digemari oleh masyarakat karena dalam penyajiannya tinggal langsung digoreng. Sehingga produk nugget dapat dijadikan produk makanan yang dapat diterima baik oleh kalangan anak-anak hingga ke kalangan orang tua.

Buah merah (Pandanus conoideus Lam) merupakan tanaman endemik Papua yang tumbuh liar di hutan-hutan. Pada daerah pedalaman Papua, ditemukan 14 varietas buah merah, tetapi yang paling populer adalah varietas merah panjang. Secara tradisional, buah merah telah dikonsumsi masyarakat Papua turun temurun sebagai sumber pangan (Sari E.K., 2008).

Buah Merah secara khusus tumbuh di pulau Papua dan sekitarnya, dan masyarakat adat telah mengkonsumsi buah merah sebagai makanan tradisional selama ribuan tahun. Buah merah adalah endemik Papua dan memiliki potensi sebagai pangan tradisional karena kandungan senyawa karotenoid yang tinggi. Area potensi pengembangan komoditas buah merah di Papua tersebar di beberapa kabupaten, antara lain Jayawijaya, Puncak Jaya, Tolikara, Yahukimo, Jayapura, Manokwari, Sorong, Merauke, Biak, Nabire, Paniai, Yapen Waropen, Mimika, dan Fakfak (Rumbarar, 2002).

Buah merah kaya akan nutrisi, sehingga dapat menawarkan berbagai manfaat. Buah merah kaya sekali akan antioksidan dan juga asam lemak (omega-3 dan omega-9). Kedua senyawa ini mampu membantu tubuh dalam menangkal radikal bebas yang dapat menyebabkan kerusakan sel serta dapat meningkatkan kekebalan tubuh.

Buah merah yang termasuk dalam famili Pandanaceae ini, oleh masyarakat lokal Papua telah banyak dimanfaatkan baik sebagai sumber bahan makanan, pewarna alami dan sebagai bahan obat tradisional, hingga sekarang buah merah tetap menjadi makanan sebagian penduduk Papua terutama yang bermukim di daerah pegunungan Jayawijaya. Buah merah terkenal dengan nama buah sejuta manfaat, buah merah mengandung zat-zat gizi dalam kadar tinggi, diantaranya betakaroten, tokoferol, asam oleat, asam linoleat, dekanoat, protein, kalsium, vitamin, energi, lemak dan serat. Buah merah (Pandanus baccari L) dapat tumbuh pada dataran rendah hingga ketinggian 2.500m dari permukaan laut (dpl), dengan kesuburan tanah rendah, asam sampai agak asam ( $\mathrm{pH} 4,30$ 5,30) (Nainggolan, 2001).

Sari buah merah mengandung senyawa antioksidan dengan kandungan yang cukup tinggi yaitu karotenoid (12.000 ppm), beta-karoten (700 ppm), dan tokoferol (11.000 ppm) (Budi, 2001). Sari buah merah dapat menghambat proliferasi sel limfosit dan pertumbuhan sel penyebab kanker sehingga angka kematian karena kanker di Indonesia dapat ditekan (Mun'im et al., 2006). Konsumsi beta-karoten rutin membuat tubuh dapat memperbanyak sel-sel alami pembasmi penyakit. Bertambahnya sel-sel tersebut akan menekan kehadiran sel kanker dengan menetralisir radikal bebas senyawa karsinogen penyebab kanker (Dermawan, 2005 dalam Puji Lestari, 2011). Bahkan, uji in vivo menggunakan hewan percobaan tikus Sparague Dawley menunjukkan bahwa buah merah mampu berperan untuk pertumbuhan dan pemeliharaan jaringan pada tikus secara optimal (Sari E.K., 2008).

Warna seperti halnya dengan citarasa, dimana citarasa sebagai pelengkap daya tarik pada produk pangan. Penambahan zat warna pada produk pangan mempengaruhi selera dan daya tarik konsumen. Berkembangnya industri pangan dapat meningkatkan pemakaian bahan pewarna. Beberapa pewarna sintetik sering dijadikan pilihan sebagai bahan tambahan makanan karena memiliki stabilitas warna yang baik tetapi mempunyai resiko terhadap kesehatan. Penggunaan pewarna sintetik dengan dosis di atas ambang batas dapat mengakibatkan gangguan metabolisme tubuh (Belitz et al, 2009). Buah merah merupakan produk unggulan Papua merupakan pangan lokal yang mendapat perhatian dari gubernur Papua yang harus dilakukan penelitian dalam berbagai bidang ilmu pengetahuan. Buah merah kaya akan nutrisi, sehingga dapat menawarkan berbagai manfaat, antara lain, penambah energi, sebagai sumber energi dan sebagai antioksidan dan lain-lain.

Sehingga dalam hal ini dilakukan pengkajian dalam penggunaan pewarna alami dari buah merah khususnya menggunakan minyak buah merah. Minyak buah merah selain melengkapi unsur lemak dalam produk nugget ayam, juga sekaligus menjadi pewarna alami agar didapatkan nugget ayam yang berwarna cantik untuk menarik secara penampilan sekaligus mempunyai kelebihan secara nutrisinya. Faktor kritis untuk proses ekstraksi minyak buah merah terletak pada tahap pemanasan, dimana parameter yang perlu dikendalikan adalah keberadaan air, suhu dan lama proses (Sarungallo Z. L. et. al., 2014). Penelitian tentang tingkat kefektifan penggunaan minyak buah merah sebagai pewarna alami perlu dilakukan lebih mendalam (Santoso B. dkk., 2011). Tujuan dari penelitian ini untuk mengetahui uji organoleptik nugget ayam terhadap warna, aroma, tekstur dan rasa nugget ayam pada berbagai konsentrasi pemberian minyak buah merah, sehingga minyak buah merah dapat dimanfaatkan sebagai produk pangan olahan pangan lokal dan lebih disukai karena bergizi dan dapat diterima oleh masyarakat.

Dengan banyaknya manfaat dari buah merah maka penelitian ini memanfaatkan minyak buah merah dalam pengolahan pangan dalam hal ini adalah nugget ayam minyak buah merah. Perumusan masalah yang diambil adalah berapa kadar persentase minyak buah merah hasil uji organoleptik dari rasa, aroma, warna dan tekstur akan nugget ayam minyak buah merah yang disukai oleh panelis. 
Penelitian ini diharapkan dapat memberikan informasi mengenai penggunaan minyak buah merah pada pangan olahan dalam hal ini nugget ayam. Dengan demikian penelitian ini dapat memberikan sumbangan terhadap eksplorasi manfaat dan khasiat minyak buah merah secara khusus hasil dari olahan tanaman buah merah.

\section{Metodologi}

\subsection{Lokasi dan Waktu Penelitian}

Pembuatan nugget ayam minyak buah merah ini dilaksanakan di Laboratorium Pengolahan Balai Latihan Pertanian Sentani Papua. Sedangkan uji organoleptik di ruang kelas Balai Latihan Pertanian Sentani Papua pada tanggal 15 dan 16 September 2020

\subsection{Alat dan Bahan Penelitian}

Alat yang digunakan yaitu timbangan digital, penggiling daging, cetakan, talenan, pisau daging, gunting daging, baskom, spatula, sendok, kompor, pengukus, wajan, penggorengan, saringan, piring, plastik dan kotak penyimpanan. Bahan yang digunakan adalah $2 \mathrm{~kg}$ daging ayam broiler. Daging ayam didapatkan dari 2 ekor ayam yang diperoleh dari Pasar Baru Sentani Papua pada pedagang yang sama. Setiap perlakuan percobaan menggunakan 250 gr daging ayam, 80-90 ml air es, 75 gr tepung tapioka, 75 gr tepung mocaf, 2 lembar roti tawar, $100 \mathrm{ml}$ susu cair tawar, 5 gr gula pasir, 5 gr garam, 2 gr merica, 2 gr baking powder, 2 butir telur ayam, 4 gr penyedap rasa, 10 gr bawang putih, 10 gr bawang bombay, 10 gr bawang merah goreng. Bahan pelapis terdiri dari 200 gr tepung tapioka, 200 gr tepung mocaf, 4 butir telur, 400 gr tepung roti, dan minyak goreng untuk menggoreng nugget ayam. Dalam pembuatan nugget ayam menggunakan persentase minyak buah merah dengan rincian sebagai berikut : dimana perlakuannya adalah $\mathrm{P} 1=0,0 \%$ minyak buah merah, $\mathrm{P} 2=0,5 \%$ minyak buah merah, $\mathrm{P} 3=1 \%$ minyak buah merah dan P4 = 1,5\% minyak buah merah.

\subsection{Prosedur Tahapan Pembuatan Nugget Ayam}

Alat yang digunakan yaitu timbangan digital, penggiling daging, cetakan, talenan, pisau daging, gunting daging, baskom, spatula, sendok, kompor, pengukus, wajan, penggorengan, saringan, piring, plastik dan kotak penyimpanan. Bahan yang digunakan adalah $2 \mathrm{~kg}$ daging ayam broiler. Daging ayam didapatkan dari 2 ekor ayam yang diperoleh dari Pasar Baru Sentani Papua pada pedagang yang sama. Setiap perlakuan percobaan menggunakan 250 gr daging ayam, 80-90 ml air es, 75 gr tepung tapioka, 75 gr tepung mocaf, 2 lembar roti tawar, $100 \mathrm{ml} \mathrm{susu}$ cair tawar, 5 gr gula pasir, 5 gr garam, 2 gr merica, 2 gr baking powder, 2 butir telur ayam, 4 gr penyedap rasa, 10 gr bawang putih, 10 gr bawang bombay, 10 gr bawang merah goreng. Bahan pelapis terdiri dari 200 gr tepung tapioka, 200 gr tepung mocaf, 4 butir telur, 400 gr tepung roti, dan minyak goreng untuk menggoreng nugget ayam. Dalam pembuatan nugget ayam menggunakan persentase minyak buah merah dengan rincian sebagai berikut : dimana perlakuannya adalah $\mathrm{P} 1=0,0 \%$ minyak buah merah, $\mathrm{P} 2=0,5 \%$ minyak buah merah, $\mathrm{P} 3=1 \%$ minyak buah merah dan P4 = 1,5\% minyak buah merah.

\subsection{Pelaksanaan Uji Organoleptik}

Uji organoleptik dalam penelitian ini adalah

a. Uji organoleptik di uji dengan 20 orang panelis semi terlatih.

b. Uji organoleptik yang di uji adalah aroma, warna, tekstur dan rasa dari nugget ayam minyak buah merah.

c. Uji organoleptik menggunakan uji hedonik yang dimana panelis akan mengutarakan tanggapan tentang nugget ayam mengenai suka dan tidak sukanya nugget ayam.

d. Skala yang dipakai adalah:

- $\quad$ Aroma: sangat harum (5), harum (4), agak harum (3), kurang harum (2) tidak harum (1);

- Warna: sangat suka (5), suka (4), agak suka (3), kurang suka (2), tidak suka (1);

Testur: sangat renyah (5), renyah (4), agak renyah (3), kurang renyah (2), tidak renyah (1).

Rasa: sangat enak (5), enak (4), agak enak (3), kurang enak (2), tidak enak (1).

e. Prosedur kerja penilaian organoleptik

Menyiapkan ruangan

Menata bahan nugget ayam minyak buah merah

Mengumpulkan panelis

Panelis diarahkan kedalam ruangan kelas yang sudah dipersiapkan untuk dijadikan tempat penilaian uji organoleptik.

Melakukan pengukuran suhu tubuh dan mencuci tangan

Membagikan kuisioner kepada panelis

Memberikan penjelasan tentang uji organoleptik kepada 20 panelis. 
- Sampel yang disediakan sebanyak 80 sampel yang terbagi atas P1:20, P2:20, dan P3:20 dan P4:20 sampel.

- Sampel akan diberikan kepada panelis satu persatu dari setiap perlakuan (4) dengan jarak waktu penilaian yakni \pm 10 - 15 menit, setiap panelis akan mendapatkan masing-masing 4 sampel dari empat perlakuan

Memberikan kesempatan agar panelis memberikan penilaiannya.

\subsection{Pelaksanaan Uji Organoleptik}

Penelitian ini dilakukan dengan menggunakan Rancangan Acak Lengkap (Sutaryo dkk., 2016 dalam Selvia Nurlaila, 2017). Perlakuan yang dimaksud, yaitu konsentrasi minyak buah merah P1 (0\%), P2 (0,5\%), P3 (1\%) dan P4 (1,5\%).

Oleh karena itu dapat diajukan suatu model analisis:

Yijk $=\mu+\tau i+\varepsilon i j$

Yijk $\quad=$ nilai pengamatan pada perlakuan ke-i \& ulangan ke-j

$\mu \quad=$ nilai tengah umum

Ti $\quad=$ pengaruh perlakuan ke-i

Eij $\quad=$ galat $\quad=$ percobaan pada perlakuan ke-i \& ulangan ke-j

Dimana perlakuannya adalah

$\mathrm{P} 1=0,0 \%$ minyak buah merah

$\mathrm{P} 2=0,5 \%$ minyak buah merah

P3 $=1,0 \%$ minyak buah merah

$\mathrm{P} 4=1,5 \%$ minyak buah merah

Analisis data mengunakan Sidik Ragam uji statistik Aplikasi R, dilanjutkan dengan menggunakan Uji Beda Nyata Terkecil (BNT) pada taraf $5 \%$.

Parameter pengamatan atau variabel dari uji organoleptik nugget ayam minyak buah merah adalah:

Warna : sangat suka (5), suka (4), agak suka (3), kurang suka (2), tidak suka (1);

Aroma : sangat harum (5), harum (4), agak harum (3), kurang harum (2) tidak harum (1);

Testur : sangat renyah (5), renyah (4), agak renyah (3), kurang renyah (2), tidak renyah (1);

Rasa : sangat enak (5), enak (4), kurang enak (3), tidak enak (2), sangat tidak enak (1).

\section{Hasil dan Pembahasan}

\subsection{Aroma}

Aroma mampunyai peranan yang sangat penting dalam penentuan derajat penilaian dan kualitas suatu bahan pangan. Selain bentuk dan warna, bau atau aroma akan berpengaruh dan menjadi perhatian utama. Setelah aroma diterima maka penentuan selanjutnya adalah cita rasa disamping teksturnya.

Menurut Setyaningsih et al., (2010), industri pangan menganggap uji bau sangat penting karena dapat dengan cepat memberikan hasil mengenai kesukaan konsumen terhadap produk.

Tabel 1. Rataan uji hedonik panelis nugget ayam minyak buah merah.

\begin{tabular}{cccccc}
\hline \multirow{2}{*}{ No. } & \multirow{2}{*}{$\begin{array}{c}\text { Konsentrasi Minyak Buah } \\
\text { Merah }\end{array}$} & \multicolumn{4}{c}{ Parameter / Variabel } \\
\cline { 3 - 5 } & & Aroma & Warna & Tekstur & Rasa \\
\hline 1 & P1 $(0 \%)$ & $3,50 \mathrm{a}$ & $2,50 \mathrm{c}$ & $3,30 \mathrm{~b}$ & $3,25 \mathrm{~b}$ \\
\hline 2 & P2 $(0,5 \%)$ & $3,65 \mathrm{a}$ & $3,65 \mathrm{~b}$ & $3,90 \mathrm{a}$ & $3,90 \mathrm{a}$ \\
\hline 3 & P3 $(1 \%)$ & $3,70 \mathrm{a}$ & $3,85 \mathrm{ab}$ & $3,75 \mathrm{ab}$ & $4,05 \mathrm{a}$ \\
\hline 4 & P4 $(1,5 \%)$ & $3,55 \mathrm{a}$ & $4,20 \mathrm{a}$ & $3,55 \mathrm{ab}$ & $3,25 \mathrm{~b}$ \\
\hline \multicolumn{4}{r}{ Keterangan: Huruf yang berbeda pada baris yang sama menunjukkan berbeda nyata pada $\alpha=0,05}$.
\end{tabular}

Berdasarkan hasil analisis R Application (Tabel 1), perbedaan konsentrasi minyak buah merah tidak berpengaruh nyata terhadap kesukaan panelis pada aroma nugget ayam minyak buah merah ( $\mathrm{p}<0,05)$. Adapun dari hasil uji terhadap aroma nugget ayam minyak buah merah diketahui tingkat aroma dipilih oleh panelis cenderung ke arah beraroma khas nugget ayam.

Dimana aroma nugget ayam minyak buah merah memiliki kisaran nilai rataan 3,50 sampai 3,70. Nilai ini menunjukkan penilaian cukup harum terhadap aroma nugget ayam minyak buah merah. Baik dengan 
penambahan minyak buah merah atau tanpa penambahan minyak buah merah rata-rata hasilnya cukup harum akan aroma nugget ayam minyak buah merah. Hal ini menunjukkan bahwa aroma nugget ayam dengan penambahan minyak buah merah tidak meningkatkan aroma nugget minyak buah merah.

Minyak buah merah memiliki aroma yang khas. Namun dengan adanya bumbu-bumbu penambahan dalam nugget ayam sehingga dapat menutupi aroma khas dari minyak buah merah. Hal tersebut mengakibatkan perbedaaan konsentrasi minyak buah merah tidak berpengaruh terhadap aroma nugget ayam minyak buah merah. Minyak buah merah tidak mempengaruhi mutu aroma nugget ayam, karena bahan campuran lainnya menutupi aroma khas minyak buah merah.

\subsection{Warna}

Daging ayam mengandung pigmen myoglobin, sedangkan minyak buah merah mengandung pigmen karotenoid yang berupa likopen sehingga dapat mempengaruhi warna nugget. Faktor penentu utama pada warna daging yaitu konsentrasi pigmen myoglobin dalam daging ayam. Myoglobin merupakan salah satu dari protein sarkoplasmik yang terbentuk dari suatu rantai polipeptida tunggal terikat yang dapat membawa oksigen (Soeparno, 1998). Protein sarkoplasmik sebagai protein yang larut dalam air dan dapat diekstrak menggunakan air atau larutan garam dengan kekuatan ion rendah (Bintoro, 2008).

Hasil nilai hedonik nugget ayam minyak buah merah terhadap warna diperoleh nilai rata-rata 2,50 sampai 4,20. Secara umum nugget ayam minyak buah merah berwarna kuning kecoklatan sampai merah muda yang dapat dilihat pada Gambar 1 .

Berdasarkan hasil analisis $R$ Application, perbedaan konsentrasi minyak buah merah berpengaruh nyata terhadap warna nugget ayam minyak buah merah $(\mathrm{p}<0,05)$. Adapun hasil uji lanjut Uji LSD (Least significant difference)/beda nyata terkecil (BNT) pada Tabel 1 menunjukkan bahwa konsentrasi minyak buah merah pada $\mathrm{P} 4=4,20 \mathrm{a}$ berbeda nyata dengan konsentrasi $\mathrm{P} 2=3,65 \mathrm{~b}$ dan $\mathrm{P} 1=2,50 \mathrm{c} ;$ konsentrasi $\mathrm{P} 3=3,85 \mathrm{ab}$ berbeda nyata dengan konsentrasi $\quad \mathrm{P} 1=2,50 \mathrm{c}$; konsentra. $\mathrm{P} 2=3,65 \mathrm{~b}$ berbeda nyata dengan konsentra $\mathrm{P} 1=2,50 \mathrm{c}$ pada $\alpha=0,05$. Sedangki

konsentrasi P4= 4,20a dan P3 $=3,85 \mathrm{ab}$ pac $\mathrm{P} 1=0 \%$ Minyak Buah Merah $\mathrm{P} 2=0,5 \%$ Minyak Buah Merah baris yang sama menunjukkan tidak berbe€a
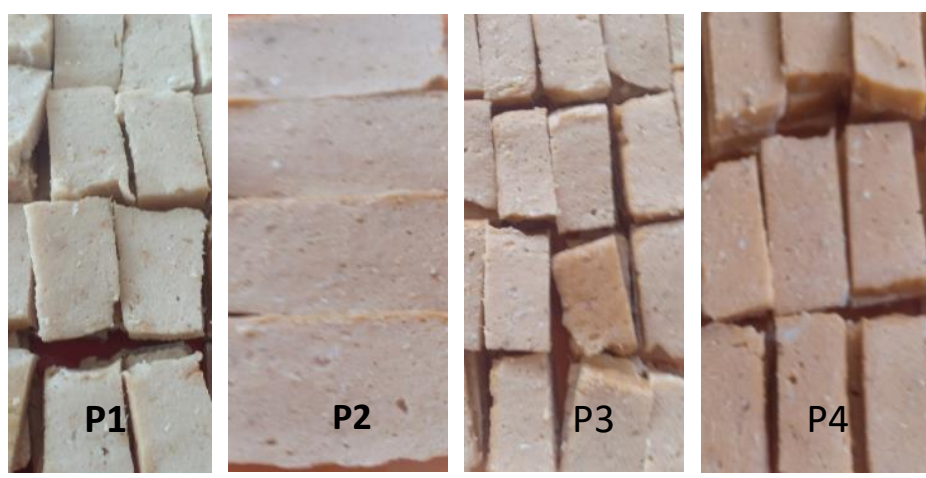

Gambar 1. Warna nugget ayam minyak buah merah

Keterangan : nyata selain itu juga P3=3,85ab dan $\mathrm{P} 2=3,65 \mathrm{~b}$ menunjukkan tidak berbeda nyata pada $\alpha=0,05$.

Proses pada pemanasan saat menggoreng nugget diduga dapat menyebabkan myoglobin yang terkandung didalam daging terdenaturasi, sehingga warna nugget menjadi agak coklat pada perlakuan P1. Intensitas warna coklat dapat berkurang karena meningkatnya substitusi penambahan minyak buah merah yang dapat menurunkan pigmen myoglobin. Menurut Soeparno (1998), menyebutkan bahwa myoglobin mengalami denaturasi pada suhu antara $80^{\circ} \mathrm{C}-85^{\circ} \mathrm{C}$. Stabilitas pigmen dalam bahan pangan sangat dipengaruhi oleh berbagai faktor lingkungan. Faktor tersebut diantaranya adalah ada tidaknya oksigen, cahaya, substansi oksidasi reduksi, unsur logam berat, aw, pH dan suhu.

Saat proses penggorengan kemungkinan menyebabkan warna pada nugget menjadi agak coklat, karena adanya reaksi pencoklatan non enzimatis dari gula pereduksi yang dikandungnya. Menurut Bintoro (2008), menyatakan bahwa warna pada daging olahan dapat diperoleh dari pengaruh cara pengolahan dan bahan yang ditambahkan. Pemberian gula dan proses pemanasan pada daging dapat menyebabkan warna coklat, dimana warna coklat tersebut didapat dari reaksi pencoklatan non enzimatik. Warna memegang peranan yang penting dalam penerimaan makanan, selain itu warna dapat memberi petunjuk terhadap perubahan kimia dalam makanan (Deman J.M., 1997).

Hal ini menunjukkan bahwa minyak buah merah yang ditambahkan pada nugget ayam disukai pada konsentrasi 1,5\% dimana minyak buah merah membuat warna produk pangan menjadi menarik (kategori suka). Hal ini sesuai dengan pendapat R. Rasbawati dan J. Rauf (2018), bahwa warna membuat produk pangan menjadi menarik. Selain itu juga menurut pendapat Febrina et al., 2007 bahwa warna merupakan faktor kualitas yang berpengaruh dan sangat utama bagi makanan. Bersama-sama dengan aroma, rasa dan tekstur warna memegang peranan penting dalam penerimaan makanan. Salah satu faktor penentu mutu bahan pangan adalah warna, karena berhubungan 
erat dengan produk akhir dari suatu pengolahan pangan (Winarno, 1997). Pendapat lain dikemukakan oleh Soekarta dkk. (1990) bahwa warna merupakan sifat produk yang dapat dipandang secara fisik dan sifat organoleptik.

\subsection{Tekstur}

Tekstur merupakan segala hal yang berhubungan dengan mekanik, rasa, sentuhan, penglihatan, dan pendengaran yang meliputi penilaian terhadap kebasahan, kering, keras, halus, kasar, dan berminyak. Penilaian tekstur makanan dapat dilakukan dengan menggunakan jari, gigi, dan langit-langit. Faktor tekstur di antaranya adalah rabaan oleh tangan, keempukan, dan mudah dikunyah.

Pada proses penggilingan kemungkinan juga mempengaruhi tekstur nugget, dimana tekstur daging ayam yang sudah digiling berbeda dengan tekstur daging ayam utuh. Hal ini disebabkan karena pada saat proses penggilingan diduga terjadi pemutusan serabut-serabut otot oleh mesin penggiling, sehingga mempengaruhi tekstur daging giling. Menurut Owens C. M. (2011), menyatakan bahwa penggilingan atau pengecilan ukuran berfungsi agar area permukaan daging meluas, sehingga dapat terjadi ekstraksi protein. Ekstraksi protein sangat penting karena apabila tidak terjadi ekstraksi maka daging tidak dapat menyatu saat dimasak, dan hal ini dapat mempengaruhi tekstur nugget yang dihasilkan.

Berdasarkan hasil analisis R Application, perbedaan konsentrasi minyak buah merah berpengaruh nyata terhadap kesukaan pada tekstur nugget ayam minyak buah merah $(\mathrm{p}<0,05)$. Adapun hasil uji lanjut Uji LSD (Least significant difference)/beda nyata terkecil (BNT) pada Tabel 1 menunjukkan bahwa konsentrasi minyak buah merah pada $\mathrm{P} 2=3,90 \mathrm{a}$ berbeda nyata dengan konsentrasi $\mathrm{P} 1=3,30 \mathrm{~b}$; konsentrasi $\mathrm{P} 2=3,90 \mathrm{ab}$ tidak berbeda nyata dengan konsentrasi $\mathrm{P} 3=3,75 \mathrm{ab}$ dan $\mathrm{P} 4=3,55 \mathrm{ab}$; konsentrasi $\mathrm{P} 1=3,30 \mathrm{~b}$ tidak berbeda nyata dengan konsentrasi $\mathrm{P} 3=3,75 \mathrm{ab}$ dan $\mathrm{P} 4=3,55 \mathrm{ab}$ pada $\alpha=0,05$.

Hal ini menunjukkan hasilnya adalah agak renyah sampai renyah terhadap tekstur nugget ayam minyak buah merah. Hasil yang paling disukai adalah tekstur nugget ayam minyak buah merah dari konsentrasi $0,5 \%$ minyak buah merah. Penambahan minyak buah merah yang berlebihan akan menyebabkan tekstur makanan tidak menjadi renyah.

Tekstur nugget ayam yang telah disubstitusi dengan minyak buah merah diduga dipengaruhi oleh penggunaan bahan pengikat yang ditambahkan. Menurut Anjarsari (2010), menyatakan bahwa bahan pengikat adalah bahan yang digunakan dalam makanan untuk mengikat air yang terdapat dalam adonan. Fungsi bahan pengikat yaitu dapat memperbaiki stabilitas emulsi, menurunkan penyusutan akibat pemasakan, memberi warna yang terang, meningkatkan elastisitas produk, membentuk tekstur yang padat dan menarik air dalam adoanan. Umumnya bahan pengikat yang ditambahkan ke dalam adonan makanan adalah bahan-bahan berpati seperti tepung tapioca, tepung beras, tepung maizena, tepung sagu dan tepung terigu.

Bahan pelapis yang digunakan juga kemungkinan dapat mempengaruhi tekstur nugget. Menurut Owens C. M. (2001), menyatakan bahwa faktor yang mempengaruhi tekstur nugget adalah penggunaan tepung roti yang digunakan akan berpengaruh terhadap kekasaran tekstur nugget yang dihasilkan. Tepung roti dengan butiran yang besar akan menghasilkan nugget dengan tekstur yang kasar dan tidak seragam, sedangkan tepung roti dengan butiran lembut akan menghasilkan tekstur yang lembut pada nugget. Hal ini disebabkan karena butiran yang menempel pada adonan nugget akan lebih merata, sehingga seluruh permukaan nugget dapat tertutup sempurna. Tekstur nugget yang lembek akan kurang disukai oleh panelis. Sebaliknya dengan tekstur yang agak kasar dapat diperoleh dengan penggunaan tepung roti yang mempunyai butiran agak besar. Permukaan yang halus dari nugget bukan merupakan karakteristik yang diharapkan oleh panelis (Herawati, 2008).

\subsection{Rasa}

Rasa merupakam faktor penentu daya terima konsumen terhadap produk pangan. Faktor rasa memegang peranan penting dalam pemilihan produk oleh konsumen. Rasa merupakan respon lidah terhadap rangsangan yang diberikan oleh suatu makanan. Indera perasa terbagi menjadi empat rasa, yaitu manis, asin, pahit, dan asam. Rasa merupakan respon lidah terhadap rangsangan yang diberikan oleh suatu makanan. Konsumen akan memutuskan menerima atau menolak produk pangan dengan empat rasa tersebut.

Berdasarkan hasil analisis R Application, perbedaan konsentrasi minyak buah merah berpengaruh nyata terhadap kesukaan rasa nugget ayam minyak buah merah $(\mathrm{p}<0,05)$. Adapun hasil uji lanjut Uji LSD (Least significant difference)/beda nyata terkecil (BNT) pada Tabel 1 menunjukkan bahwa konsentrasi minyak buah merah pada $\mathrm{P} 3=4,05 \mathrm{a}$ dan $\mathrm{P} 2=3,90 \mathrm{a}$ berbeda nyata terhadap konsentrasi $\mathrm{P} 1=3.25 \mathrm{~b}$ dan $\mathrm{P} 4=3,25 \mathrm{~b}$; sedangkan konsentrasi P3 $=4,05$ a terhadap konsentrasi $\mathrm{P} 2=3,90 \mathrm{a}$ dan pada konsentrasi $\mathrm{P} 1=3,25 \mathrm{~b}$ terhadap P4=3,25b menunjukkan tidak berbeda nyata pada $\alpha=0,05$. Hal ini menunjukkan bahwa tingkat konsentrasi yang di sukai adalah rasa nugget minyak buah merah pada konsentrasi $0,5 \%(\mathrm{P} 2)$ dan $1 \%(\mathrm{P} 3)$.

Rasa nugget ayam minyak buah merah yang disukai panelis memiliki kisaran nilai rataan 3,90 sampai 4,05. Nilai ini menunjukkan penilaian enak terhadap rasa nugget ayam minyak buah merah. Dengan adanya penambahan 
minyak buah merah pada pembuatan nugget ayam memberikan rasa enak. Menurut Winarno, 2004 penerimaan panelis terhadap rasa dipengaruhi oleh beberapa faktor antara lain senyawa kimia, suhu, konsentrasi dan interaksi dengan komponen lainya.

Rasa nugget kemungkinan merupakan faktor yang paling berpengaruh terhadap kesukaan panelis. Rasa nugget hampir dapat dipastikan berbanding lurus dengan kesukaan panelis. Semakin enak dan gurih rasanya, semakin besar tingkat kesukaan panelis terhadap produk nugget yang disajikan, dan sebaliknya. Berdasarkan komentar dari para panelis, tekstur nugget yang paling disukai panelis adalah agak kasar. Hal ini disebabkan karena tekstur yang agak kasar memberikan sensasi perlawanan saat digigit sehingga panelis merasa lebih nikmat saat mengunyah. Tingkat kesukaan panelis juga menurun pada nugget yang mempunyai tekstur kasar. Tekstur yang kasar akan memberi kesan terlalu kering pada produk dan rasa gurihnya kurang dapat dirasakan. Hal ini sesuai dengan pendapat Herawati (2008), yang menyatakan bahwa permukaan yang halus dari nugget bukan merupakan karakteristik yang diharapkan oleh panelis dan panelis menempatkan unsur rasa sebagai faktor yang paling mempengaruhi penerimaan nugget, diikuti oleh unsur aroma dan warna nugget. Lemak dalam bahan baku dapat menyebabkan lebih enaknya nugget tersebut, karena lemak dapat mengabsorpsi dan menambah flavor (Ismadi S. D., 1990). Pengolahan dan pemasakan bertujuan untuk menghasilkan makanan yang bercita rasa tinggi, sehingga rasanya nikmat dan memuaskan bagi yang memakannya (Priwindo S., 2009).

\section{Kesimpulan}

Pengkajian ini bertujuan untuk mengetahui uji organoleptik nugget ayam terhadap warna, aroma tekstur dan rasa nugget ayam pada berbagai persentase penambahan minyak buah merah, sehingga minyak buah merah dapat dimanfaatkan sebagai produk pangan olahan pangan lokal dan lebih bergizi serta dapat diterima oleh masyarakat.

Berdasarkan uji organoleptik akan nugget ayam minyak buah merah dapat disimpulkan bahwa dengan penambahan minyak buah merah pada nugget ayam cukup harum, memberikan warna yang menarik atau disukai karena warnanya. Penambahan minyak buah merah tidak lebih dari 0,5\% terhadap tekstur renyah. Dan penambahan $1 \%$ minyak buah merah memberi rasa enak terhadap nugget ayam.

Dari hasil uji organoleptik ini kami sarankan untuk menguji daya tahan/daya simpan nugget ayam minyak buah merah terhadap kualitas atau berkembangnya jamur. Selain itu dapat diuji laboratorium untuk nilai gizi yang terkandung dalam masing-masing perlakuan nugget ayam minyak buah merah.

\section{Daftar Referensi}

Anjarsari B. 2010. Pangan Hewani Fisiologi Pasca Mortem dan Teknologi. Yogyakarta : Graha Ilmu.

Belitz HD, Grosch W, and Schieberle P. 2009. Food Chemistry. 4th Revised and Extended ed. Berlin : SpringerVerlag Heidelberg.

Bintoro VP. 2008. Teknologi Pengolahan Daging dan Analisis Produk. Semarang : Universitas Diponegoro.

Budi IM. (2001). Kajian kandungan zat gizi dan sifat fisio kimia jenis minyak buah (Pandanus conoideus Lam.) hasil ekstraksi secara tradisional di kabupaten Jayawiajaya Propinsi Irian jaya. Bogor: Institut Pertanian Bogor.

Budi IM dan Paimin FR. (2005). Buah merah. Jakarta: Penebar Swadaya.

Deman JM. 1997. Kimia Makanan. Bandung: Penerbit ITB.

Dermawan dalam Puji Lestari. 2011. Isolasi dan identifikasi komponen kimia ekstrak etanol buah merah (Pandanus conoideus Lam.). Skripsi. Fakultas MIPA Jurusan Kimia. Surakarta : UNS.

Febrina E, Gozali D, dan Rusdiana T. 2007. Formulasi Sediaan Buah Merah (Pandanus conoideus) Sebagai Produk Antioksidan Alami. Laporan Penelitian Muda.

Herawati. 2008. Produksi karkas, hasil olahan dan perubahan histologi organ dan jaringan ayam broiler dengan suplemen fitobiotik jahe merah. Disertasi Program Studi Ilmu Peternakan Sekolah Pascasarjana, Yogyakarta : Universitas Gadjah Mada.

Ismadi SD. 1990. Nutrisi dan Kesehatan Pusat Antar Universitas Pangan dan Gizi. Yogyakarta : Universitas Gadjah Mada.

Limbongan J dan Malik A. 2009. Peluang Pengembangan Buah Merah (Pandanus conoideus Lam.) di Provinsi Papua. Jurnal Litbang Pertanian, 28(4), 134-141.

Mun'im AR, Andrajati dan H Susilowati. 2006. Uji hambatan tumorigenesis sari buah merah (Pandanus conoideus Lam.) terhadap tikus putih betina yang diinduksi 7,12 dimetilbenz (A) Antrasen (Dmba). Majalah Ilmu Kefarmasian 3(3), 153-161.

Nainggolan D. 2001. Aspek Ekologis Kultivar Buah Merah Panjang (Pandanus conoideus Lam.) di Daerah Dataran Rendah Manokwari. Skripsi Fakultas Kehutanan. Manokwari : Universitas Negeri Papua. 
Owens CM. 2001. Poultry Meat Processing. CRC Press LCC. Department of poultry science, Texas. (edited by A., R., Sams).

Priwindo S. 2009. Pengaruh pemberian tepung susu sebagai bahan pengikat terhadap kualitas nugget angsa. Skripsi. Medan : Universitas Sumatera Utara.

R Rasbawati, J Rauf. 2018. Kadar protein tepung ceker ayam dan tingkat kesukaan biscuit dengan substitusi tepung ceker. Jurnal Galung Tropika, 7(2), 115-122.

Rumbarar L. 2002. Kebijakan Pembangunan Wilayah Perkebunan Jayapura. BPTP Papua.

Sari EK. 2008. Mempelajari Khasiat buah merah (Pandanus conoideus Lam.) terhadap kualitas pertumbuhan dan fungsi hati secara in vivo. Tesis. Fakultas Teknologi Pertanian Bogor : IPB.

Sarungallo ZL, Hariyadi P, Andarwulan N and Purnomo EH. 2014. Pengaruh metode ekstraksi terhadap muti kimia dan komposisi asam lemak minyak buah merah (Pandanus conoideus). Jurnal Teknologi Industri Pertanian 24(3), $209-217$.

Setyaningsih D. 2010. Isolasi dan identifikasi komponen utama ekstrak biji buah merah (Pandanus conoideus Lamk.). Skripsi. Fakultas MIPA. Semarang : UNS.

SNI (Standar Nasional Indonesia) 01-3741-2002. Minyak Goreng. 2002. Jakarta : Badan Standarisasi Nasional.

Soekarta dan Soewarno T. 1990. Dasar-dasar Pengawasan dan Standarisasi Mutu Pangan. Bogor : Institut Pertanian Bogor.

Soeparno. 1998. Ilmu dan Teknologi Daging. Yogyakarta : Gadjah Mada Press.

Sutaryo dalam Selvia Nurlaila. 2017. Uji organoleptik terhadap berbagai bahan dasar nugget. Jurnal Maduranch 2(2).

Winarno FG. 1997. Kimia Pangan dan Gizi. Jakarta : PT. Gramedia Pustaka Utama.

Winarno FG. 2004. Kimia Pangan dan Gizi. Jakarta : PT. Gramedia Pustaka Utama. 